\title{
ONE-YEAR RESULTS OF BRACING FOR PATELLO-FEMORAL OSTEOARTHRITIS. PROSPECTIVE RANDOMIZED STUDY
}

\author{
UM ANO DE USO DE ÓRTESE PARA OSTEOARTRITE FÊMORO- \\ PATELAR. ESTUDO PROSPECTIVO RANDOMIZADO
}

\author{
Matheus Garcia lopes Merino ${ }^{1}$ (1), Victor Morale ${ }^{1}$ (1), Guilherme Pereira Ocampos ${ }^{1}$ (1), Maria Cândida Miranda Luzo ${ }^{1}$ (1), \\ Olavo Pires de Camargo ${ }^{1}$ (1), Márcia UChoa de Rezende ${ }^{1}$ (i)
}

1. Universidade de São Paulo, Faculty of Medicine, Hospital das Clínicas, Institute of Orthopedics and Traumatology, HC-FMUSP, São Paulo, SP, Brazil.

\section{ABSTRACT}

Objective: To compare the long-term effects of a brace designed to stabilize the patellofemoral (PF) joint in comparison to a standard neoprene sleeve for the knee with patellar hole in patients with patellofemoral osteoarthritis (PFOA). Methods: 38 patients with PFOA and comorbidities received either a functional PF brace (Study Group, SG) or a neoprene sleeve for the knee (Control Group, CG). Both groups received clinical treatment to $\mathrm{OA}$ and comorbidities according to a program from the institution. Patients were evaluated with Western Ontario and MacMaster (WOMAC) and Lequesne questionnaires, 30-second chair stand test (30CST), Timed Up and Go (TUG), anthropometric measures and self-reported physical activity in minutes/week at inclusion, one, three and twelve months after placing the brace. X-Rays were taken to measure the angles. Results: At one year there was more abandonment in the CG without differences in weight and body mass index between groups during the study. The SG maintained improvements in Lequesne and WOMAC total and subsets during the year, whereas the CG returned to baseline values for pain, function and total ( $p<0.01)$. TUG and 30CST results were always better in the study group without any clinically important improvement in both groups. Conclusion: Long-term use of functional brace added to self-management program improves pain and function in patients with PFOA. Level of Evidence II, Lesser quality RCT (eg, < $80 \%$ followup, no blinding, or improper randomization).

Keywords: Osteoarthritis. Orthotic Devices. Patellofemoral Pain Syndrome.

\section{RESUMO}

Objetivo: Comparar o efeito a longo prazo de uma órtese destinada a estabilizar a articulação fêmoro-patelar em comparação com uma de neoprene com orifício para patela em pacientes com osteoartrite fêmoro-patelar (OAFP). Métodos: Trinta e oito pacientes com OAFP e comorbidades receberam ou uma órtese funcional fêmoro-patelar (grupo estudo, GE) ou uma joelheira de neoprene com orifício para patela (grupo controle, GC). Os grupos receberam tratamento clínico da osteoartrite e comorbidades conforme programa da instituição. Foram avaliados com os questionários de WOMAC e Lequesne, testes de senta e levanta em 30 segundos (TSL30) e Timed-Up-and-Go (TUG), medidas antropométricas e minutos de atividade física semanal à inclusão, com um, três e doze meses depois da colocação da órtese. Radiografias foram realizadas para mensurar ângulos fêmoro-tibiais. Resultados: Houve mais abandono no GC, sem diferenças de peso, índice de massa corpórea e atividade física entre os grupos durante o estudo. GE manteve melhoras de Lequesne e WOMAC total e subdomínios durante todo o estudo, enquanto o GC piorou progressivamente após o primeiro mês ( $p<0,01)$. TUG e TSL30 tiveram melhoras não clinicamente relevantes para ambos os grupos. Conclusão: O uso a longo prazo da órtese funcional adicionado ao tratamento clínico melhora a dor e a função dos pacientes com OAFP. Nível de Evidência II, Evidence II,ECRC de menor qualidade (por exemplo, $<80 \%$ de acompanhamento, sem mascaramento do código de randomização ou randomização inadequada).

Descritores: Osteoartrite. Aparelhos Ortopédicos. Síndrome da Dor Patelofemoral.

Citation: Merino MGL, Morale V, Ocampos GP, Luzo MCM, Camargo OP, Rezende MU. One-year results of bracing for patello-femoral osteoarthritis. Prospective randomized study. Acta Ortop Bras. [online]. 2021;29(3):127-131. Available from URL: http://www.scielo.br/aob.

\section{INTRODUCTION}

Osteoarthritis (OA) has the fastest growing prevalence of all musculoskeletal diseases with greatest indirect health costs in terms of years of healthy life lost due to disease and disability adjusted life years. ${ }^{1}$ Of the weight-bearing joints, the knee is the most commonly affected by $\mathrm{OA} .^{2}$ Most intervention studies have focused on the femorotibial (FT) joint, whereas OA of the patellofemoral (PF) joint, either in isolation or combined with FT OA, is reported to be more

All authors declare no potential conflict of interest related to this article.

The study was conducted at Universidade de São Paulo, Hospital das Clínicas, Faculty of Medicine, Osteometabolic Diseases Group of the Institute of Orthopedics and Traumatology. Correspondence: Marcia Uchôa de Rezende. Rua Dr. Ovídio Pires de Campos, 333, 3o Andar, Sala 317-B, São Paulo, SP, Brazil, 05403010. marcia.uchoa@hc.fm.usp.br 
prevalent. ${ }^{3}$ PFOA is a significant source of knee pain and disability, ${ }^{4}$ with known abnormal gait patterns such as increased mechanical load (i.e., knee flexion moment, impulse and patellofemoral joint stress) during the second half of the stance phase. 5,6

Research on PFOA suggests that altered mechanics are indicators of a poor prognosis. Medially directed therapeutic taping and bracing are frequently used to modify the position and kinematics of the patella. Both techniques are hypothesized to produce a medial translation of the patella and increase joint contact forces, thereby reducing joint stress on the lateral compartment. ${ }^{7}$

Treating PFOA with medially directed tape and braces improves pain and bone marrow lesions. ${ }^{8-12}$ The use of a brace to stabilize the knee with medial, lateral, superior and inferior compression bands also improved pain not differently from a sleeve with patella hole. ${ }^{11}$ The aim of this study is to verify the long-term effects of these two braces $^{11}$ in pain and function of patients with PFOA.

\section{MATERIALS AND METHODS}

This is a prospective randomized study approved by the Ethics Committee for Analysis of Research Projects (CAPPesq) (number 15016/16 and Clinical Trials registration number NCT02984254). All patients signed an informed consent form after receiving a detailed explanation.

The diagnosis of PFOA was made using the clinical criteria of the $A C R,{ }^{13}$ i.e., presence of symptoms (pain and sensitivity) in the patellofemoral compartment of the knee, associated with signs of $O A$ according to the Kellgren and Lawrence (K\&L) classification. ${ }^{14}$ Alignment was examined through long leg X-rays, tracing the mechanical axis (from the center of the femoral head to the center of the ankle) and the femorotibial angles. When long leg $X$-rays were not available, the femoro-tibial angle was measured in anterior-posterior knee X-rays.

The inclusion criteria were:

1) Symptomatic PFOA, absence of patella dislocation;

2) Age $\geq 30$ years;

3) Clinical treatment for knee osteoarthritis for more than 6 months. Non-inclusion criteria included:

4) Patients with involvement of the femoro-tibial compartment of the knee;

5) Patients unable to read or understand the consent form or the Western Ontario McMaster Universities (WOMAC) questionnaire:15

6) Patients with grade II or higher obesity.

The exclusion criteria were:

1) Braces used differently from what was requested;

2) Abandonment of the study;

3) Non-adaptation to the brace;

4) Skin and vascular complications due to brace use.

Procedure: at inclusion, the 60 patients were divided into three blocks and allocated to one of the two groups according to the order given by the spreadsheet 6591 created on April 12, 2017, at 8:58:36 in www.randomization.com.

At baseline, all patients arrived early to the hospital where they informed their age, schooling in years and number of minutes per week they exercised (self-reported). Weight and height were measured and patients performed the thirty-second chair-stand test (30CST), ${ }^{16}$ Timed Up and Go (TUG) ${ }^{17}$ and answered the WO$M_{A C}{ }^{15}$ and Lequesne ${ }^{18}$ questionnaires. They attended a half-day course on osteoarthritis and its forms of treatment based on a self-management program for patients with knee OA of the institution, and finally had the braces placed in their knees according to randomization. Patients allocated to the study group (SG) used the Free Knee $\AA$ : patellofemoral functional brace (Figure 1a, Technical characteristics: knee brace made of neoprene with upper, lower, and lateral impact absorption system), whereas the control group
(CG) used Neoprene knee brace with a patellar orifice and support (Figure 1b, Technical characteristics: patella-shaped neoprene knee brace with lateral reinforcement).

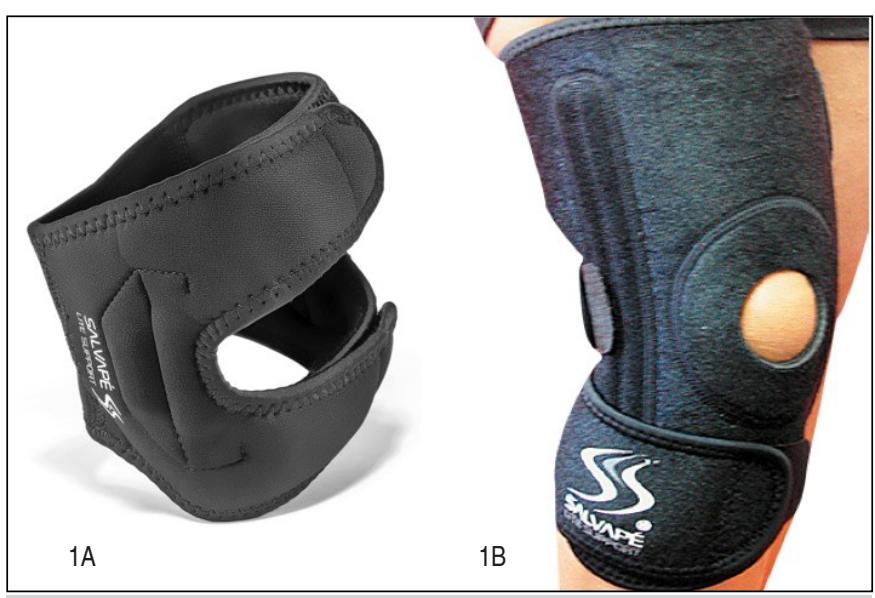

Figure 1. A) Functional knee brace (Free Knee®, Salvapé, made of neoprene with Velcro and rubber tubes in the upper, lower, and lateral parts of the patella); B) Neoprene knee brace (Knee brace with patellar orifice, Salvapé, neoprene, and Velcro)

Patients were instructed to use the brace for 2 hours on the first day and increase by half an hour per day from the second day, up to a maximum of 12 hours/day. Patients were instructed to sleep without the device and use it when performing physical activities, except for activities performed in water.

Follow-up evaluations were made one, three and 12 months after knee brace placement.

Radiography without the brace (Schuss view and profile and axial views of the patella) to measure the affected joint spaces was performed in all patients. Long leg radiographies were not performed in all patients at inclusion.

Sample calculation: "n" was calculated to obtain a statistical power of $80 \%$ and a significance level of $5 \%$. To this end, we considered the standard deviation of the WOMAC variation in the study by Campos et al., ${ }^{19}$ with a similar population of patients with knee OA from the Institute of Orthopedics and Traumatology. The sample size was selected so that it allowed the detection of a 5-point WOMAC variation. Considering eventual dropouts of about $10 \%$ of the patients, 26 patients per group was obtained as the recommended sample size.

\section{Statistical analysis}

The normal distribution of most of the data was verified by the Shapiro-Wilk test. Age, schooling (in years), physical activity, weight, $\mathrm{BMl}$ and the distribution of the femorotibial angle according to knee brace were compared by an independent t-test. Sex according to groups and condition of the knee at $X$-rays was compared using Pearson's chi-square test.

The scores of the questionnaires and functional tests were compared by an ANOVA test with repetitive measures. The analyses were followed by Bonferroni's multiple comparisons to determine the point at which significant differences between the groups and evaluation periods occurred. The analyses were performed using IBM's SPSS version 24.0. The tests were performed with a $5 \%$ significance level. 


\section{RESULTS}

This study is the long-term follow-up of a study ${ }^{11}$ comparing two different PF knee braces. The study commenced with 30 patients in each arm. Three patients (one from the CG and two from the SG) abandoned the study before retrieving the knee brace. One patient in each group missed evaluation at three months, not returning to the study. Thirteen patients from the control group did not attend the one-year evaluation, whereas only one from the study group missed the one-year evaluation. The study ended with 14 in the control group and 24 in the study group.

Table 1 shows descriptive variables regarding knee bracing at baseline. Groups were similar at inclusion for age, schooling, physical activity, weight and BMI. Despite more women than men, gender was equally distributed between the two models of PF bracing (Table 2).

Physical activity and weight improved with a non-significant BMI change in both groups (Table 3 ).

The SG maintained WOMAC total and subset improvements at one-year, whereas CG returned to baseline values for WOMAC pain, function and total (Table 4). The same pattern was seen with Lequesne's algo-function questionnaires (Table 5). TUG and 30CST results were always better in the SG without any clinically significant improvement in both groups (Table 5).

Table 1. Baseline descriptive variables according to groups.

\begin{tabular}{|c|c|c|c|c|c|c|c|}
\hline & \multicolumn{2}{|c|}{ CG } & \multicolumn{2}{|c|}{ SG } & \multirow{2}{*}{$t$} & \multirow[b]{2}{*}{$p$} & \multirow{2}{*}{ ES } \\
\hline & $\mathrm{n}$ & Mean \pm SD & $\mathrm{n}$ & Mean \pm SD & & & \\
\hline Age & 29 & $65.31 \pm 7.6$ & 28 & $63.00 \pm 7.9$ & 1.12 & 0.26 & 0.15 \\
\hline Schooling & 29 & $7.90 \pm 4.10$ & 28 & $8.29 \pm 6.4$ & -0.27 & 0.78 & 0.04 \\
\hline $\mathrm{PA}$ & 29 & $136.03 \pm 157.5$ & 28 & $74.63 \pm 8.3$ & 0.27 & 0.78 & 0.04 \\
\hline Weight & 29 & $74.63 \pm 8.4$ & 26 & $73.17 \pm 11.1$ & 0.555 & 0.58 & 0.07 \\
\hline BMI & 29 & $29.51 \pm 3.2$ & 27 & $27.57 \pm 6.4$ & 1.42 & 0.16 & 0.19 \\
\hline
\end{tabular}

CG: Control Group; SG: Study Group; PA: Physical Activity; BMI: Body Mass Index; SD: standard deviation; $t$ : independent $t$ test; $p<0.05$; ES: effect size.

Table 2. Absolute and relative gender frequencies according to group.

\begin{tabular}{|c|c|c|c|c|c|c|c|c|}
\hline & \multicolumn{2}{|c|}{ CG } & \multicolumn{2}{|c|}{ SG } & \multirow{2}{*}{$x^{2}$} & \multirow{2}{*}{$p$} & \multicolumn{2}{|c|}{ Total } \\
\hline & $n$ & $\%$ & $\mathrm{n}$ & $\%$ & & & $n$ & $\%$ \\
\hline Female & 25 & 43.9 & 22 & 38.6 & 0.16 & 0.68 & 47 & 82.5 \\
\hline Male & 4 & 7.00 & 6 & 10.5 & & & 10 & 17.5 \\
\hline
\end{tabular}

$x^{2}$ : Pearson's Chi-square; $p<0.05$.

Table 3. Comparison of the descriptive variables during the study.

\begin{tabular}{|c|c|c|c|c|c|c|c|c|}
\hline & & \multicolumn{2}{|c|}{ Baseline } & 1 month & 3 months & 1 year & \multirow[b]{2}{*}{$p$} & \multirow{2}{*}{ ES } \\
\hline & & $\mathrm{n}$ & Mean \pm SD & Mean \pm SD & Mean \pm SD & Mean \pm SD & & \\
\hline \multirow[t]{2}{*}{$\mathrm{PA}$} & $C G$ & 14 & $180.00 \pm 165.6$ & $225.36 \pm 262.0$ & $182.86 \pm 189.8$ & $216.43 \pm 176.9$ & 0.50 & 0.02 \\
\hline & SG & 25 & $131.00 \pm 137.4$ & $158.00 \pm 156.1$ & $215.80 \pm 148.2$ & $201.00 \pm 252.6$ & & \\
\hline \multirow[t]{2}{*}{ Weight } & CG & 14 & $75.20 \pm 6.9$ & $74.41 \pm 7.2$ & $73.27 \pm 7.0$ & $73.54 \pm 7.2$ & 0.33 & 0.03 \\
\hline & SG & 23 & $73.22 \pm 11.5$ & $72.96 \pm 11.6$ & $73.2 \pm 12.6$ & $72.51 \pm 10.9$ & & \\
\hline BMI & CG & 14 & $29.68 \pm 3.0$ & $29.35 \pm 3.1$ & $28.98 \pm 2.8$ & $29.44 \pm 3.0$ & 0.16 & 0.04 \\
\hline & $S G$ & 23 & $28.40 \pm 3.9$ & $28.25 \pm 3.8$ & $28.62 \pm 4.4$ & $28.46 \pm 4.1$ & & \\
\hline
\end{tabular}

PA: Physical Activity; BMI: Body Mass Index; CG: Control Group; SG: Study Group; SD: standard deviation; p < 0.05; ES: effect size.

Table 4. Comparison of WOMAC total and subsets results.

\begin{tabular}{|c|c|c|c|c|c|c|c|c|c|c|}
\hline & & \multicolumn{2}{|c|}{ Baseline } & \multirow{2}{*}{$\begin{array}{c}1 \text { month } \\
\text { Mean } \pm \text { SD }\end{array}$} & \multirow{2}{*}{$\begin{array}{c}3 \text { months } \\
\text { Mean } \pm \text { SD }\end{array}$} & \multirow{2}{*}{$\begin{array}{c}1 \text { year } \\
\text { Mean } \pm \text { SD }\end{array}$} & \multirow{2}{*}{$p^{a}$} & \multirow{2}{*}{$p^{b}$} & \multirow{2}{*}{$p^{c}$} & \multirow{2}{*}{ ES } \\
\hline WOMAC & & $\mathrm{n}$ & Mean \pm SD & & & & & & & \\
\hline \multirow[t]{2}{*}{ Pain } & $C G$ & 14 & $9.57 \pm 3.0$ & $6.79^{*} \pm 4.0$ & $7.43 \pm 4.8$ & $10.29^{\star \star} \pm 4.5$ & 0.03 & 0.02 & 0.01 & 0.02 \\
\hline & $S G$ & 24 & $8.25 \pm 4.2$ & $6.79 \pm 3.8$ & $6.29 \pm 4.3$ & $6.46^{\mathrm{B4}} \pm 4.2$ & & & & \\
\hline \multirow[t]{2}{*}{ Stiffness } & $C G$ & 14 & $4.71 \pm 1.7$ & $3.00^{*} \pm 1.8$ & $3.5 \pm 1.9$ & $4.07 \pm 2.2$ & 0.01 & 0.01 & 0.03 & 0.11 \\
\hline & $S G$ & 24 & $3.13^{\mathrm{B} 1} \pm 2.4$ & $2.38 \pm 1.6$ & $2.75 \pm 2.0$ & $2.58 \pm 2.3$ & & & & \\
\hline \multirow[t]{2}{*}{ Funtion } & $C G$ & 14 & $31.79 \pm 11.0$ & $24.57 \pm 14.3$ & $30.14 \pm 16.0$ & $35.5^{\star \star} \pm 12.8$ & 0.01 & 0.01 & 0.02 & 0.10 \\
\hline & $S G$ & 24 & $29.88 \pm 15.2$ & $24.00 \pm 13.6$ & $22.54 \pm 14.6$ & $23.75^{\mathrm{B4}} \pm 15.5$ & & & & \\
\hline \multirow[t]{2}{*}{ Total } & $C G$ & 14 & $46.07 \pm 12.7$ & $35.79 \pm 18.1$ & $41.21 \pm 21.9$ & $49.86^{\star \star} \pm 18.4$ & 0.01 & 0.01 & 0.01 & 0.11 \\
\hline & SG & 24 & $41.25 \pm 20.8$ & $33.17 \pm 18.1$ & $31.58 \pm 19.8$ & $32.79^{84} \pm 21.2$ & & & & \\
\hline
\end{tabular}

CG: Control Group; SG: Study Group; SD: standard deviation; *: different from baseline; **: different from 1 month; $p^{\mathrm{a}}$ : $p$ group; $p^{\mathrm{b}}$ : $p$ moment; $p^{\mathrm{c}}$ : $p$ interaction; $p<0.05 ;$ ES: Effect Size. ${ }^{\text {B1: }}$ Different from $C G$ at baseline; ${ }^{B 4}$ : Different from $C G$ at one-year. 
Table 5. Comparison of Lequesne, Timed Up and Go (TUG) and 30 seconds chair stand test (30CST) results.

\begin{tabular}{|c|c|c|c|c|c|c|c|c|c|c|}
\hline & & \multicolumn{2}{|c|}{ Baseline } & 1 month & 3 months & 1 year & $p^{a}$ & $p^{b}$ & $p^{c}$ & ES \\
\hline & & $\mathrm{n}$ & Mean \pm SD & Mean \pm SD & Mean \pm SD & Mean \pm SD & & & & \\
\hline \multirow[t]{2}{*}{ LEQ } & $C G$ & 14 & $12.42 \pm 3.3$ & $8.82^{*} \pm 4.0$ & $11.07 \pm 5.2$ & $11.75 \pm 4.3$ & 0.01 & 0.01 & 0.03 & 0.11 \\
\hline & $S G$ & 24 & $10.66 \pm 5.1$ & $8.97 \pm 3.9$ & $8.89 \pm 4.4$ & $8.25^{\mathrm{B} 4} \pm 4.9$ & & & & \\
\hline \multirow[t]{2}{*}{ TUG } & $C G$ & 14 & $12.11 \pm 3.9$ & $11.52 \pm 3.0$ & $11.78 \pm 2.9$ & $11.85 \pm 3.9$ & 0.04 & 0.06 & 0.04 & 0.01 \\
\hline & $S G$ & 24 & $10.16^{\mathrm{B} 1} \pm 2.8$ & $10.47 \pm 2.1$ & $10.01 \pm 1.8$ & $10.25 \pm 3.0$ & & & & \\
\hline \multirow[t]{2}{*}{$30 \mathrm{CST}$} & $C G$ & 14 & $7.65 \pm 3.1$ & $8.29 \pm 2.5$ & $8.06 \pm 2.9$ & $8.47 \pm 2.7$ & 0.38 & 0.82 & 0.46 & 0.02 \\
\hline & $S G$ & 24 & $8.84 \pm 2.0$ & $8.88 \pm 2.71$ & $9.24 \pm 2.9$ & $9.32 \pm 3.4$ & & & & \\
\hline
\end{tabular}

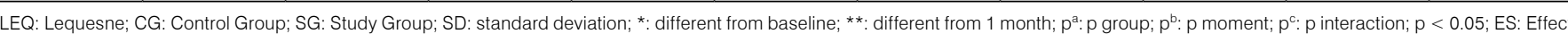
Size. ${ }^{\text {B1: }}$ Different from $C G$ at baseline; ${ }^{\text {B4: }}$ Different from $C G$ at one-year.

Thirty-seven patients had long-leg X-rays. Among them, 61.1\% had valgus alignment and $35.2 \%$ varus. One patient (3.7\%) had one knee varus and one valgus.

\section{DISCUSSION}

While symptoms and progression of PFOA is known to be related to poor mechanics, ${ }^{7}$ interventions such as patella taping, patella bracing and physical therapy can alleviate joint stress and symptoms for people with this condition. ${ }^{4}$ Medially directed PF bracing produces medial translation of the patella, reduces lateral patella tilt and increases joint contact forces, reducing joint stress on the lateral compartment. ${ }^{20}$ Treating PFOA by bracing reduces pain, bone marrow lesions and improves function at short term. ${ }^{8,10,11}$

The purpose of this study was to verify the long-term effects (one year) of the usage of two PF braces that had no significant difference in results at short term. Both braces led to reduced medication consumption in the first month and some stopped taking medication based on the results obtained at the third month follow-up. ${ }^{11}$ The CG received a standard sleeve with patella hole and the SG used a new model developed to increase joint contact forces while compressing the circumference of the patella (functional brace). At one-year follow-up, six patients abandoned the SG and 16 abandoned the $\mathrm{CG}$. These were significant losses since both groups started with 30 patients. Descriptive variables such as weight, physical activity, body mass index, distribution of gender by type of brace and groups remained constant in both groups despite losses. However, the improvements in the SG were better with time, whereas the return to baseline scores were more evident in the CG for WOMAC total and subsets and Lequesne's algo-functional questionnaires. This result could be explained by a superiority of the functional brace but may be the result of the losses. When estimating the number of participants, 23 patients were estimated to be necessary to show a difference between braces. Crossley et al. ${ }^{8}$ also lost a similar number of patients at nine months follow-up but started with a larger number of patients and similar to our SG, maintained the gains at 3 months until the end of the study (nine months).

Functional tests (30CST and TUG) showed no clinically important improvement in both groups. The 30CST tests the PF joint more specifically than the TUG, and as expected of patients with exclusive PFOA, TUG results were close to normal and 30CST were below normal in both groups without relevant improvements provided by either brace. There was an expected greater prevalence of valgus alignment in both groups.

Among the limitations of our study are the lack of control of the number of daily hours of brace usage, lack of measurement of improvement in patellar positioning and patellar tilt to assess whether there is real improvement in patellar alignment with the use of the knee brace. These are all aims for future studies.

\section{CONCLUSION}

Long-term use of functional brace added to self-management program improves pain and function in patients with PFOA.

\section{ACKNOWLEDGMENTS}

We would like to thank the support received from the secretaries (especially Lívia Oliveira Abreu and Suellen do Nascimento Lima), physical therapists, physical educators, nutritionists and security guards of the Department of Orthopedics and Traumatology. This study was conducted with the support of the Department of Orthopedics and Traumatology (Hospital das Clínicas HCFMUSP, Faculdade de Medicina, Universidade de Sao Paulo, Sao Paulo, SP, BR), partial sponsorship of the PARQVE program by TRB Pharma ${ }^{\text {TM }}$ Brazil, and donation of the knee braces by Salvapé Produtos Ortopédicos Ltda.

AUTHORS' CONTRIBUTIONS: Each author contributed individually and significantly to the development of the article. MGLM: participated in the study execution, data analysis, and manuscript writing; VM: participated in the study execution, data analysis, and manuscript writing; GPO: participated in the project conception, study execution, data analysis, and manuscript writing; MCML: participated in the project conception; OPC: participated in manuscript writing; MUR: participated in the project conception, study execution, data analysis, and manuscript writing.

\section{REFERENCES}

1. Hunter DJ, Schofield D, Callander E. The individual and socioeconomic impact of osteoarthritis. Nat Rev Rheumatol. 2014;10(7):437-41.

2. Lawrence RC, Helmick CG, Arnett FC, Deyo RA, Felson DT, Giannini EH, et al. Estimates of the prevalence of arthritis and selected musculoskeletal disorders in the United States. Arthritis Rheum. 1998;41(5):778-99.

3. Duncan RC, Hay EM, Saklatvala J, Croft PR. Prevalence of radiographic osteoarthritis -it all depends on your point of view. Rheumatology (Oxford). 2006;45(6):757-60.
4. Hinman RS, Crossley KM. Patellofemoral joint osteoarthritis: an important subgroup of knee osteoarthritis. Rheumatology (Oxford). 2007;46(7):1057-62.

5. Liao TC, Teng HL, Link TM, Majumdar S, Souza RB. Association Between Gait Kinetics and Symptomatic Progression in Persons With Patellofemoral With/Without Concurrent Tibiofemoral Osteoarthritis. J Orthop Res. 2019;37(12):2593-600.

6. Teng HL, MacLeod TD, Kumar D, Link TM, Majumdar S, Souza RB. Individuals with isolated patellofemoral joint osteoarthritis exhibit higher mechanical loading at the knee during the second half of the stance phase. Clin Biomech (Bristol, Avon). 2015;30(4):383-90. 
7. Mills K, Hunter DJ. Patellofemoral joint osteoarthritis: an individualised pathomechanical approach to management. Best Pract Res Clin Rheumatol. 2014;28(1):73-91.

8. Crossley KM, Vicenzino B, Lentzos J, Schache AG, Pandy MG, Ozturk H, Hinman RS. Exercise, education, manual-therapy and taping compared to education for patellofemoral osteoarthritis: a blinded, randomised clinical trial. Osteoarthritis Cartilage. 2015;23(9):1457-64.

9. Hinman RS, Crossley KM, McConnell J, Bennell KL. Efficacy of knee tape in the management of osteoarthritis of the knee: blinded randomised controlled trial. BMJ. 2003;327(7407):135.

10. Callaghan M, Parkes MJ, Forsythe LM, Williams HE, Stirling F, Felson DT. Beneficial effects of a brace for patellofemoral OA: results of a randomised trial. Osteoarthritis Cartilage. 2013;21:S23.

11. Yamamoto GJ, Ocampos GP, Luzo MCM, Silva CAC, Farias FES, Rezende MU. Randomized prospective study on the treatment of femoro-patellar osteoarthritis using bracing. Acta Ortop Bras. 2019;27(2):85-91.

12. Hunter DJ, Harvey W, Gross KD, Felson D, McCree P, Li L, et al. A randomized trial of patellofemoral bracing for treatment of patellofemoral osteoarthritis. Osteoarthritis Cartilage. 2011;19(7):792-800.

13. Altman R, Asch E, Bloch D, Bole G, Borenstein D, Brandt K, et al. Development of criteria for the classification and reporting of osteoarthritis. Classification of osteoarthritis of the knee. Diagnostic and Therapeutic Criteria Committee of the American Rheumatism Association. Arthritis Rheum. 1986;29(8):1039-49.
14. Kellgren JH, Lawrence JS. Radiological assessment of rheumatoid arthritis. Ann Rheum Dis. 1957;16(4):485-93.

15. Fernandes MI. Tradução e validação do questionário de qualidade de vida específico para osteoartrose WOMAC (Western Ontario McMaster Universities) para a língua portuguesa [master's thesis]. São Paulo: Universidade Federal de São Paulo; 2003 [accessed on 2019 June 24]. Available from: http://www. repositorio.unifesp.br/handle/11600/19401

16. Gill S, McBurney H. Reliability of performance-based measures in people awaiting joint replacement surgery of the hip or knee. Physiother Res Int 2008;13(3):141-52.

17. Podsiadlo D, Richardson S. The timed "Up \& Go": a test of basic functional mobility for frail elderly persons. J Am Geriatr Soc. 1991;39(2):142-8.

18. Marx FC, Oliveira LM, Bellini CG, Ribeiro MCC. Tradução e validação cultural do questionário algofuncional de Lequesne para osteoartrite de joelhos e quadris para a língua portuguesa. Rev Bras Reumatol. [Internet]. 2006 [accessed on 2019 Jun 24];46(4):253-60. Available from: http://www.scielo.br/pdf/\%0D/rbr/ v46n4/31820.pdf

19. Campos GC, Rezende MU, Pailo AF, Frucchi R, Camargo OP. Adding triamcinolone improves viscosupplementation: a randomized clinical trial. Clin Orthop Relat Res. 2013;471(2):613-20.

20. McWalter EJ, Hunter DJ, Harvey WF, McCree P, Hirko KA, Felson DT, et al. The effect of a patellar brace on three-dimensional patellar kinematics in patients with lateral patellofemoral osteoarthritis. Osteoarthritis Cartilage. 2011;19(7):801-8. 